\title{
SuPPlier SELECTION AND ASSESSMENT: Their IMPACT ON BUSINESS PERFORMANCE ${ }^{1}$
}

\author{
Vijay R. Kannan \\ Department of Business Administration \\ Utah State University \\ Logan, UT 84322-3510 \\ Tel/Fax: (435) 797-7212/2634 \\ vkannan@b202.usu.edu \\ Keah Choon Tan \\ Department of Management \\ University of Nevada, Las Vegas \\ 4505 Maryland Parkway, Box 456009 \\ Las Vegas, NV 89154-6009 \\ Tel/Fax: (702) 895-3873/4370 \\ kctan@nevada.edu
}

September 10, 2001

\footnotetext{
${ }^{1}$ This research was sponsored by the APICS E\&R Foundation, and The Supply Chain Council, Inc, Research Grant \#: 99-15
} 


\title{
SuPPlier SELECTION AND ASSESSMENT: THEIR IMPACT ON BUSINESS PERFORMANCE
}

\begin{abstract}
As firms increasingly focus on their core competencies and increase their use of outsourcing for non-core activities, they are forced to increase their reliance and dependence on suppliers. This increases the importance of effective supplier selection and assessment. Little evidence exists regarding the impact of supplier selection and assessment on a buying firm's business performance. This research describes an empirical study of the importance of supplier selection and assessment criteria of American manufacturing companies for items to be used in products already in production. Moreover, it identifies relationships between criteria and a buying firm's business performance. Results indicate that soft, nonquantifiable selection criteria such as a supplier's strategic commitment to a buyer, have a greater impact on performance than hard, more quantifiable criteria such as supplier capability, yet are considered to be less important. Assessment of a supplier's willingness and ability to share information also has a significant impact on the buying firm's performance, yet is again considered to be relatively unimportant.
\end{abstract}

Key Words: Supply Assessment, Supplier Selection, Purchasing, Business Performance 


\section{INTRODUCTION}

In recent years, there has been a shift amongst manufacturing companies away from vertical integration towards smaller, leaner operations (Prahalad \& Hamel, 1990). Organizations have downsized, focused on core competencies, and attempted to achieve competitive advantage by leveraging their suppliers' capabilities and technologies. Many have reduced their supplier base so they can more effectively manage relationships with strategic suppliers (Tully, 1995), and developed cooperative, mutually beneficial relationships with suppliers (Mason, 1996, Copacino, 1996). By exploiting their supplier's capabilities, they anticipate improvements in product quality, quicker integration of technological breakthroughs into their products, and shorter new product development lead times (Ragatz et al., 1997). Suppliers can also be involved in product design at an earlier stage, and in doing so, generate more cost-effective design choices, develop alternative conceptual solutions, select the best components and technologies, and help in design assessment (Monczka et al., 1994, Burt \& Soukup, 1985).

Increasing reliance on suppliers increases the need to effectively manage suppliers. Three dimensions underlie supplier management, the need to effectively select suppliers, develop suppliers to address shortcomings, and meaningfully assess their performance. While firms differ in the specific tactics used to manage suppliers, certain trends can be observed. Quantifiable or 'hard' criteria (Ellram, 1991) such as price, delivery, quality, and service are routinely used for supplier selection and assessment (Hahn et al., 1990). 'Soft', hard to quantify factors such as management compatibility and strategic direction of the supplier have also been shown to be important, particularly in the context of strategic buyer/supplier partnerships (Ellram, 1990). The use of site visits, training, and alternative suppliers are frequently used to stimulate improved supplier performance (Krause, 1997). While much has been written about the importance of supplier management and the tactics used to do so, little evidence exists regarding the impact of specific tactics on performance. Krause et al., (2000) examined the impact of supplier development on supplier performance, and Vonderembse and Tracey (1999) investigated the impact of supplier selection and involvement on the buying firm's manufacturing performance. However, no evidence exists on the impact of supplier management on a buying firm's business performance. This 
study uses a survey to examine relationships between the perceived importance of supplier selection and assessment criteria for items being used in production, and business performance.

\section{SUPPLIER SELECTION AND ASSESSMENT}

Using the categorization scheme in Ellram (1990), supplier selection research can be categorized as either descriptive, describing actual practice, or prescriptive, modeling how suppliers should be selected given a set of selection criteria. Descriptive studies have addressed a wide array of issues. Early studies focused on identifying the criteria used by buyers to select suppliers (e.g., Dickson, 1966, Lehmann \& O'Shaugnessy, 1982). These have been extended to identify supplier selection under specific buying conditions, for example strategic buyer/supplier partnerships (Ellram, 1990), single versus multiple sourcing (Swift, 1995), routine versus non routine purchases (e.g., White, 1978, Dempsey, 1978, Johnson, 1981, Lehmann \& O’Shaugnessy, 1982), and direct versus indirect materials (Technical Marketing Consultants, 1985). Several studies have also examined the relative importance of different selection criteria under different buying conditions (e.g., Lehmann \& O’Shaugnessy, 1974, 1982, Evans, 1982, Wilson, 1994). While cost, quality, and delivery performance have been consistently identified as being important determinants of supplier selection, it is also apparent that specific criteria and their relative importance are highly dependent on the type of purchase being made. A study by Verma \& Pullman (1998) investigated whether selection criteria are consistent with their perceived importance in the eyes of purchasing managers. While quality was determined to be the most important selection criterion, selection decisions were more likely to be made on the basis of cost and delivery performance.

A number of studies have addressed supplier selection in the light of contemporary business pressures. Choi \& Hartley (1996) examined supplier selection for companies at different points in the supply chain. Several studies have addresses issues pertinent to purchases made in global markets (e.g., Min, et al., 1994, Thorelli \& Glowacka, 1995, Deng \& Wortzel, 1995, Katsieas \& Leonidou, 1996, Piercy et al., 1997). Two recent studies have examined the impact of environmental pressures on buying behavior (Dobilas \& McPherson, 1997, Min \& Galle, 1997). There has also been interest in recent years 
in supplier selection in specific industry settings such as the Japanese electronic component industry (Hirakubo \& Kublin, 1998), systems/software (Gustin et al., 1997), and healthcare (Lambert et al., 1997).

Prescriptive research in supplier selection has used a variety of methodologies including mathematical programming (e.g., Turner, 1988, Pan, 1989), weighted average methods (Timmerman, 1986, Thompson, 1990), payoff matrices (Soukup, 1987), and the analytic hierarchy process (Narasimhan, 1983, Nydick \& Hill, 1992, Babarosoglu \& Yazgac, 1997)2.

A number of studies have examined the criteria used by buying firms to assess supplier performance (e.g., Monczka \& Trecha, 1988, Giunipero \& Brewer, 1993, Watts \& Hahn, 1993, Walton et al., 1998, Carr \& Pearson, 1999). The evidence suggests that while cost is the primary criterion, quality, delivery, and service, are also commonly used.

Despite the volume of research, particularly in the area of supplier selection, little attempt has been made to identify the impact of supplier selection and assessment on the buying company's business performance. Vonderembse \& Tracey (1999) surveyed purchasing managers with the intent of determining the extent to which manufacturing companies used various supplier selection and supplier involvement tactics, and how these impacted manufacturing performance. While there was extensive use of the supplier selection criteria presented, the same was not true for supplier involvement. Moreover, both supplier selection and involvement had a positive impact on supplier performance and on the manufacturing performance of the buying firm. Manufacturing performance was measured using a single factor that encompassed production and rework costs, quality and delivery of finished goods, and work in process inventory levels. The study did not however attempt to relate supplier selection and involvement to broader measures of business performance nor did it identify the impact of supplier management tactics on individual manufacturing performance metrics. The study did identify that high performing companies placed greater importance on selection and involvement tactics providing support for the assertion that supplier selection and involvement are important determinants of the buying firm's performance. Tan et al., (1998) showed that the use of certain supplier performance metrics had a limited impact on supplier

\footnotetext{
${ }^{2}$ A comprehensive review of modeling approaches to supplier selection can be found in De Boer et al., (2001).
} 
performance. Their study did not however extend to examining the impact on the buyer's business performance.

\section{SURVEY METHODOLOGY}

A survey was developed to collect data for this study. Three sources were used to identify supplier selection and assessment criteria: previous literature, discussions with practitioners, and company specific manuals. Based on these sources, thirty criteria used to select suppliers were identified (Appendix 1). These reflect a variety of supplier attributes including cost, quality, delivery performance, capability, and culture. For each criterion, respondents were asked to evaluate its importance to their firm in supplier selection, using a five point scale $(5=$ high importance, $1=$ low importance. Thirteen metrics commonly used to assess supplier performance were also identified (Appendix 1). Respondents were asked to evaluate the importance placed on each by their firm in supplier assessment $(5=$ high importance, $1=$ low importance). Business performance was operationalized using four measures of performance that reflect financial, market, and product performance (Appendix 1). Following the approach used in Tan et al. (1998), respondents were asked to evaluate their firm's performance in comparison to that of major competitors in their respective industries.

The survey instrument was pre-tested for content validity by thirty senior purchasing and materials managers. Where necessary, questions were re-worded to improve validity and clarity. Pre-test questionnaires were not used in subsequent analyses. The revised instrument was sent to senior materials

and purchasing managers in the U.S. who were members of either the National Association of Purchasing Management (NAPM) or the American Production and Inventory Control Society (APICS). It was assumed that respondents were familiar with their organizations' supplier management activities and could make reasonable judgments regarding firm performance relative to that of industry competitors.

A total of forty five hundred surveys were mailed. An original mailing, a reminder, and a second reminder including another survey, were sent to each respondent at two week intervals. Four hundred and eleven usable surveys were returned. To investigate the possibility of non-response bias in the data, surveys were tested for statistically significant differences in the responses of early and late waves of 
returned surveys, the latter considered representative of non-respondents (Armstrong \& Overton, 1977, Lambert \& Harrington, 1990). Ten survey items were randomly selected and t-tests carried out on mean scores of early and late responses. In addition, differences in the number of employees and annual sales of early and late responses were examined. Both sets of tests yielded no statistically significant differences suggesting that non-response bias was not present. $t$ tests were also carried out to verify that responses from the NAPM and APICS samples were not statistically different.

\section{RESULTS}

\section{Demographic and Descriptive Statistics}

Approximately $18 \%$ of responses came from raw material and component manufacturers, $43 \%$ from final product manufacturers, and $14 \%$ from wholesalers and retailers. The remaining firms included third party logistics providers, hospitals, gas and utility companies, and companies involved in warehousing, health care, software, and telecommunications. Companies varied in size from 3 to 30,000 employees with a median of 500, and had annual sales (1999) of between $\$ 5,000$ and $\$ 59$ billion, with a median of \$ 125 million. More than 50\% of respondents reported an increase in outsourcing activities for primary materials and component parts over the previous three years. Approximately $50 \%$ of respondents indicated that their firms had increased the number of key suppliers they used over the last three years, and $40 \%$ reported a decrease in their supplier base for primary materials and component parts over the same time period. These observations are consistent with organizations rationalizing their supply activities and attempting to leverage supplier capabilities.

Not surprisingly, due date performance and quality ranked as the most important supplier selection criteria (Table 1). Tukey multiple comparisons indicated that differences in mean scores of these two criteria compared to those of the remaining criteria were statistically significant $(\alpha=0.05)$. Price and capability also ranked among the more important selection criteria. Interestingly, 'soft' selection criteria did not rank among the more important selection criteria. Indeed, cultural compatibility had one of the 


\begin{tabular}{|c|c|}
\hline Selection Criterion & Mean Score* \\
\hline 1. Ability to meet delivery due dates & \begin{tabular}{l|l}
4.62 & -1
\end{tabular} \\
\hline g. Commitment to quality & 4.60 \\
\hline e. Technical expertise & 4.25 \\
\hline m. Price of materials, parts and services & 4.16 \\
\hline p. Honest and frequent communications & 4.11 \\
\hline dd. Reserve capacity or the ability to respond to unexpected demand & 4.08 \\
\hline f. Industry knowledge & 4.06 \\
\hline n. Financial stability and staying power & 4.03 \\
\hline i. Supplier's process capability & 3.98 \\
\hline cc. Commitment to continuous improvement in product and process & 3.98 \\
\hline b. Ethical standards & 3.92 \\
\hline h. Open to site evaluation & 3.90 \\
\hline k. References/reputation of supplier & 3.86 \\
\hline q. Flexible contract terms and conditions & 3.79 \\
\hline c. Testing capability & 3.77 \\
\hline v. Supplier has strategic importance to your firm & 3.76 \\
\hline d. Scope of resources & 3.69 \\
\hline t. Past and current relationship with supplier & 3.63 \\
\hline bb. Willingness to integrate supply chain management relationship & 3.39 \\
\hline w. Supplier's willingness to share confidential information & 3.37 \\
\hline o. Supplier's effort in eliminating waste & 3.29 \\
\hline aa. Supplier's ability to make a decent profit for supplying to you & 3.25 \\
\hline u. Suppliers' effort in promoting JIT principles & 3.24 \\
\hline z. Your annual orders as a percentage of their overall business & 3.15 \\
\hline j. Insurance and litigation history & 3.14 \\
\hline r. Geographical compatibility/proximity & 3.07 \\
\hline y. Supplier's order entry and invoicing system, including EDI & 3.03 \\
\hline s. Cultural match between the companies & 2.90 \\
\hline x. Percentage of supplier's work commonly subcontracted & 2.87 \\
\hline a. Company size & 2.67 \\
\hline
\end{tabular}

* Lines indicate groupings based on Tukey multiple comparisons

Table 1. Elements of Supplier Selection

lowest means scores. Quality, on-time delivery, response time, and service, rank as the most important supplier assessment criteria (Table 2). This is consistent with results of studies that suggest these criteria are also the most commonly used (e.g., Watts \& Hahn, 1993, Giunipero \& Brewer, 1993). While cost is considered to be important, it ranked among the middle of the thirteen assessment criteria considered. 


\begin{tabular}{lc|}
\hline \multicolumn{1}{c}{ Assessment Criterion } & Mean Score* \\
\hline a. Quality level & 4.73 \\
b. Service level & 4.62 \\
d. On-time delivery & 4.57 \\
k. Quick response time in case of emergency, problem, or special request & 4.44 \\
i. The flexibility to respond to unexpected demand changes & 4.27 \\
c. Correct quantity & 4.15 \\
e. Price/cost of product & 4.10 \\
l. Willingness to change their products and services to meet your changing needs & 3.88 \\
j. Communication skills/systems (phone, fax, email, internet) & 3.79 \\
m. Willingness to participate in your firm's new product development and value analysis & 3.57 \\
h. Presence of certification or other documentation & 3.50 \\
g. Willingness to share sensitive information & 3.10 \\
f. Use of Electronic Data Interchange (EDI) & 2.69 \\
\hline * Lines indicate groupings based on Tukey multiple comparisons &
\end{tabular}

* Lines indicate groupings based on Tukey multiple comparisons

Table 2. Elements of Supplier Assessment

\section{Multivariate Analysis}

Prior to assessing the impact of supplier selection and assessment on performance, reliability and factor analysis were conducted. Reliability analysis provides a measure of the ability of the survey instrument to produce consistent results from one administration to the next, or the degree to which measures are free from random error. One commonly used measure of reliability is Cronbach's $\alpha$ (Cronbach, 1951). The minimum generally acceptable value for Cronbach's $\alpha$ is 0.70 (Nunnally, 1978). Values of Cronbach's $\alpha$ for the multi-item constructs corresponding to supplier selection and assessment are shown in Table 3. In each case, the value of $\alpha$ exceeded the minimum acceptable value, thus each scale can be considered to be a reliable measure of the corresponding construct.

\begin{tabular}{ccl}
\hline Criterion & $\alpha$ & \multicolumn{1}{c}{ Notes } \\
\hline Supplier Selection & 0.939 & $\begin{array}{l}\text { When items a and m were dropped, the value of } \alpha \text { increased to } \\
\text { 0.941. These items were omitted from subsequent analysis }\end{array}$ \\
Supplier Evaluation & 0.841 & $\begin{array}{l}\text { When item e was dropped, the value of } \alpha \text { increased to } 0.843 . \\
\text { This item was omitted from subsequent analysis }\end{array}$ \\
\hline
\end{tabular}

Table 3. Reliability Analysis

Factor analysis was carried out to reduce each scale to a smaller number of underlying factors, similar to the approach used by Choi and Hartley (1996). Principal Components Analysis was used to 
extract factors (eigen values $>1$ ) and Varimax rotation used to obtain a more interpretable factor matrix. The Bartlett Test of Sphericity and the Kaiser-Meyer-Olkin measure of sampling adequacy were used to validate the use of factor analysis. With few exceptions, items had factor loadings of at least 0.50 . The exceptions, four selection criteria (ethical standards, process capability, supplier reputation, and percentage of work subcontracted) and two evaluation criteria (presence of certification documentation, and communication skills), had loadings of between 0.4 and 0.49 on their respective factors. While loadings of this magnitude suggest that these items do correlate with other items in the corresponding factors, the extent of correlation does not reach the commonly used standard for factor loadings of 0.5 . The items and were thus omitted from subsequent analysis.

The twenty-four remaining supplier selection criteria were reduced to five underlying factors (Table 4). These reflect a strategic commitment of the supplier to the buyer, the ability of the supplier meet buyer needs, supplier capability, the fit between the buyer and supplier, and the honesty and integrity of the supplier. The five factors accounted for $59 \%$ of total variance in the data. Tukey multiple comparisons of mean scores for each factor revealed that ability to be meet buyer needs was the most important (mean score $=4.17)$, followed by capability $($ mean $=3.94)$, honesty and integrity $($ mean $=3.44)$, strategic commitment of supplier $($ mean $=3.31)$, and buyer/supplier fit $($ mean $=3.20)$. All differences between mean scores were statistically significant.

The ten remaining supplier evaluation measures were reduced to three factors (Table 5). These reflect delivery and service quality, responsiveness on the part of suppliers to changing buyer needs, and information sharing. The three constructs accounted for $61 \%$ of total variance in the data. Tukey multiple comparisons of mean scores for each factor indicated that delivery and service quality had the highest mean score $(4.52)$, followed by responsiveness (mean $=4.05)$ and information sharing (2.89). Differences in mean scores were statistically significant.

Preliminary analysis of correlations between supplier selection and assessment factors and performance revealed that all significant coefficients are positive (Table 6). Correlations of supplier selection factors with firm performance suggest that ability to meet buyer needs, supposedly the most 


\begin{tabular}{|c|c|c|}
\hline Factor & Scale Item & $\begin{array}{c}\text { Factor } \\
\text { Loadings }\end{array}$ \\
\hline $\begin{array}{c}\text { SS.1 } \\
\text { Strategic } \\
\text { commitment of } \\
\text { supplier to } \\
\text { buyer }\end{array}$ & $\begin{array}{l}\text { bb. Willingness to integrate supply chain management relationship } \\
\text { y. Supplier's order entry and invoicing system, including EDI } \\
\text { v. Supplier has strategic importance to your firm } \\
\text { u. Suppliers' effort in promoting JIT principles } \\
\text { z. Your annual orders as a percentage of their overall business } \\
\text { aa. Supplier's ability to make a decent profit for supplying to you } \\
\text { w. Supplier's willingness to share confidential information }\end{array}$ & $\begin{array}{l}.745 \\
.624 \\
.623 \\
.618 \\
.570 \\
.553 \\
.530 \\
\end{array}$ \\
\hline $\begin{array}{c}\text { SS. } 2 \\
\text { Ability to meet } \\
\text { buyer needs }\end{array}$ & $\begin{array}{ll}\text { 1. } & \text { Ability to meet delivery due dates } \\
\text { p. } & \text { Honest and frequent communications } \\
\text { g. } & \text { Commitment to quality } \\
\text { cc. } & \text { Commitment to continuous improvement in product and process } \\
\text { dd. } & \text { Reserve capacity or the ability to respond to unexpected demand } \\
\text { q. } & \text { Flexible contract terms and conditions } \\
\text { n. } & \text { Financial stability and staying power } \\
\end{array}$ & $\begin{array}{l}.716 \\
.694 \\
.638 \\
.581 \\
.565 \\
.557 \\
.540\end{array}$ \\
\hline $\begin{array}{c}\text { SS.3 } \\
\text { Capability }\end{array}$ & 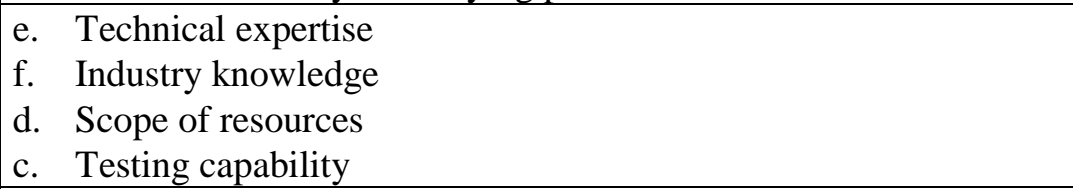 & $\begin{array}{l}.733 \\
.732 \\
.710 \\
.645\end{array}$ \\
\hline $\begin{array}{c}\text { SS.4 } \\
\text { Buyer/supplier } \\
\text { fit } \\
\end{array}$ & $\begin{array}{ll}\text { r. } & \text { Geographical compatibility/proximity } \\
\text { s. } & \text { Cultural match between the companies } \\
\text { t. } & \text { Past and current relationship with supplier }\end{array}$ & $\begin{array}{l}.729 \\
.676 \\
.581\end{array}$ \\
\hline $\begin{array}{l}\text { SS.5 } \\
\text { Honesty and } \\
\text { integrity }\end{array}$ & $\begin{array}{ll}\text { j. } & \text { Insurance and litigation history } \\
\text { h. } & \text { Open to site evaluation } \\
\text { o. } & \text { Supplier's effort in eliminating waste }\end{array}$ & $\begin{array}{l}.698 \\
.535 \\
.532\end{array}$ \\
\hline
\end{tabular}

Table 4. Factor Analysis: Supplier Selection

\begin{tabular}{|c|c|c|}
\hline Factor & Scale Item & $\begin{array}{c}\text { Factor } \\
\text { Loadings }\end{array}$ \\
\hline \multirow{4}{*}{$\begin{array}{c}\text { SA.1 } \\
\text { Delivery and } \\
\text { Service Quality }\end{array}$} & b. Service level & .804 \\
\hline & d. On-time delivery & .738 \\
\hline & a. Quality level & .726 \\
\hline & c. Correct quantity & .625 \\
\hline \multirow{4}{*}{$\begin{array}{c}\text { SA.2 } \\
\text { Responsiveness }\end{array}$} & 1. Willingness to change products, services to meet your changing needs & .816 \\
\hline & k. Quick response time in case of emergency, problem, or special request & .725 \\
\hline & m. Willingness to participate in new product development, value analysis & 669 \\
\hline & i. The flexibility to respond to unexpected demand changes & .662 \\
\hline \multirow{2}{*}{$\begin{array}{c}\text { SA.3 } \\
\text { Information } \\
\text { Sharing }\end{array}$} & f. Use of Electronic Data Interchange (EDI) & .844 \\
\hline & g. Willingness to share sensitive information & .793 \\
\hline
\end{tabular}

Table 5. Factor Analysis: Supplier Evaluation

important factor, correlates positively only with product quality. Capability, which ranked second in importance, correlates positively with both product quality and competitive position. However strategic 


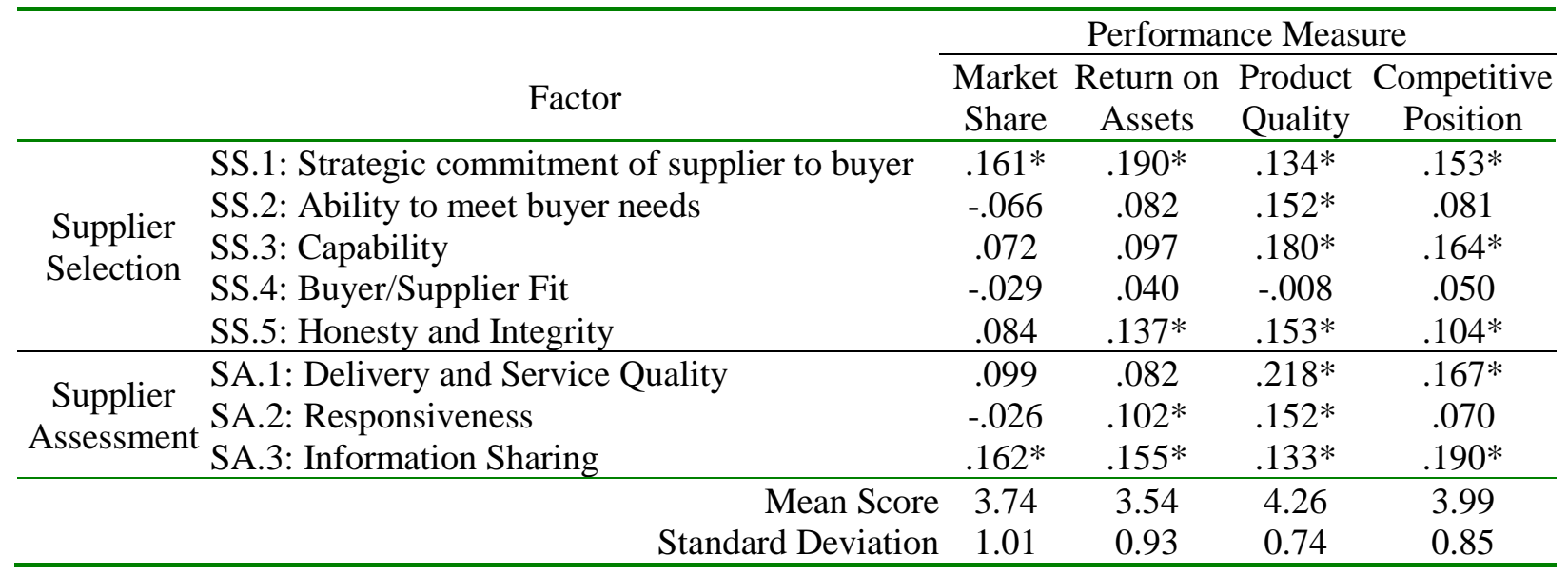

* indicates significance at $\alpha=0.05$ level

Table 6. Correlation Analysis

commitment of the supplier, and honesty and integrity, correlate more broadly with performance, strategic commitment in particular correlating positively with all measures of business performance. Buyer/supplier fit, which ranked last in importance, does not correlate positively with performance.

Correlation of the supplier assessment criteria with performance measures shows that delivery and service quality correlate positively with product quality and competitive position, while responsiveness correlates positively with product quality and return on assets. However, information sharing, which is deemed to be the least important dimension of supplier assessment, correlates positively with all performance measures.

\section{IMPLICATIONS FOR SUPPLIER MANAGEMENT}

Several observations can be made regarding the relationship between the supplier selection and its impact on performance. The ability to meet buyer needs, deemed to be the most important factor, correlates positively only with product quality, while supplier capability, which is second in importance, correlates positively with only product quality and competitive position. These two factors are operational in nature, focusing primarily on the ability of a supplier to deliver according to buyer expectations. High quality delivered goods impacts the quality of the buying firm's products, thus the positive correlation with product quality, and in the case of capability, competitive position. Market share and return on assets are performance measures that reflect long term behavior of the buying firm. Improving long-term 
performance requires not only a buying firm's strategic commitment to improved supply chain performance, but a corresponding commitment from its partners. As the results indicate, market share correlates positively only with a supplier's strategic commitment to the buyer, and return in assets correlates only with the supplier's strategic commitment to the buyer and its honesty and integrity. It is of note that with the exception of buyer/supplier fit, 'soft' factors have a broader impact on performance than others. This observation lends support to the conclusion of Ellram (1990), that in the context of strategic partnerships, soft selection criteria are important. The results here however indicate that regardless of whether a firm is engaged in strategic partnerships, soft selection criteria can have a considerable impact on their performance. Not only does this suggest a need to reduce the emphasis on traditional, measurable supplier attributes, it suggests the need to consider the buyer/supplier relationship more closely in supplier selection decisions. It should also be pointed out that while supplier capability and ability to be a meet buyer needs are pertinent in all buying situations, the same is not true of a strategic commitment of a supplier to a buyer. This explains why strategic commitment ranked only fourth in importance among all supplier selection factors.

Not surprisingly, there is a positive correlation between the assessment of a supplier's delivery and service quality performance and the buying firm's product quality and competitive position. The ability of the buying firm to deliver quality products in a timely manner is to a large extent a function of the ability of its suppliers to meet required delivery and quality standards. However, high performing suppliers also supply to other companies, some of which may be competitors of the buying firms included in this study. This suggests that a supplier's delivery and service quality may not impact broader measures of market performance such as return on assets and market share. These measures are more likely to be affected by the strategic positioning of the buying firm, and attempts to incorporate suppliers into their supply chain strategy. The positive correlation between a supplier's responsiveness and return on assets is significant. Not only does it suggest that supplier responsiveness enables a buying firm to respond more rapidly to market forces, but that it allows buying firms to use their own resources more effectively. The only supplier assessment factor to correlate positively with all performance measures, information 
sharing, is also considered to be the least important. This is an important observation for a number of reasons. While information sharing is believed to be a critical factor in improving supply chain performance by facilitating planning and scheduling, reducing the need to carry inventory, and improving the nature and speed of communication between buyers and suppliers, the results here empirically validate what has in the past been no more than an assumed relationship between information flow and performance. Equally important is the fact that despite the realization that information flow affects a supplier's business performance, buying firms do not consider it important to assess the willingness and ability of suppliers to share information. This may be a result of firms not knowing how to assess information flow, or not recognizing its importance.

\section{CONCLUSIONS}

This study demonstrates the importance of supplier selection and assessment on a buying firm's business performance. A strategic commitment from suppliers is clearly a vital determinant of business success. Not only does it directly impact performance as the results demonstrate, it can also have an indirect impact. It is for example easier to address supplier delivery and quality problems if there is a relationship between buyer and supplier, and if there are shared expectations and objectives. This however requires that firms develop relationships with suppliers who are willing to develop closer ties, have order entry systems that support the relationship, are willing to share confidential information, and are otherwise committed to serving the buyer's long term needs. The study also re-iterates the need to view suppliers as extensions of the buying firm itself and not as independent entities to be dealt with at arms length.

It is also evident that a need exists for some firms to re-assess their supplier management tactics. While there is support for a wide variety of tactics, the observation that those having the greatest impact on performance are not those considered most important represents an opportunity for buyers. While the lack of evidence on linkages between tactics and performance may have contributed to this outcome, it is no doubt also a result of the fact that developing long term relationships with suppliers, and critically evaluating soft, hard to measure dimensions of performance, takes time and can be a costly proposition. 
From a practical standpoint, the results have important implications both for purchasing managers and academics. The need to place more emphasis on relationship building may require changes in both how buyers are trained and in how buyer/supplier communications are conducted. Not only may changes be needed in the nature and tone of communications, the increased strategic significance of relationships may necessitate changes in the players involved. From an academic perspective, the results suggest the need for further study of buyer/supplier communication processes. They also suggest a need to develop metrics that allow the effectiveness of buyer/supplier relationships to be assessed. Without such metrics, not only will the tendency to steer clear of selection and assessment criteria that cannot be quantified continue, there will be no way to gauge whether a firm is making progress in developing relationships.

\section{REFERENCES}

An Evaluation of Industrial Purchasing and Distribution Trends: A Research Investigation, American Machinery Manufacturers Association Cleveland, OH, 1985.

Armstrong, J. S., and Overton, T.S., "Estimating non-response bias in mail surveys", Journal of Marketing Research, (14:3), 1977, pp. 396-402.

Barbarosoglu, G., and Tulin, Y., "An Application of the Analytic Hierarchy Process to the Supplier Selection Problem", Production and Inventory Management, (38:1), 1977, pp. 14-21.

Burt, D.N., and Soukup, W.R., "Purchasing's Role in New Product Development", Harvard Business Review, (63:5), 1985, pp. 89-97.

Carr, A.S., and Pearson, J.N., "Strategically Managed Buyer-Supplier Relationships and Performance Outcomes", Journal of Operations Management, (17:5), 1999, pp. 497-519.

Choi, T.Y., and Hartley, J.L., "An Exploration of Supplier Selection Practices Across the Supply Chain”, Journal of Operations Management, (14:4), 1996, pp. 333-343.

Copacino, W.C., "Seven Supply Chain Principles”, Traffic Management, (35:1), 1996, p. 60.

Cronbach, L.J., "Coefficient Alpha and the Internal Structure of Tests," Psychometrika, (16), 1951, pp. 297-334.

de Boer, L., Labro, E., and Morlacchi, P., “A Review of Methods Supporting Supplier Selection", European Journal of Purchasing and Materials Management, (7), 2001, pp. 75-89.

Dempsey, W.A., "Vendor Selection and the Buying Process", Industrial Marketing Management, (7), 1978, pp. 257-267.

Deng, S., and Wortzel, L.H., "Importer Purchase Behavior: Guidelines for Asian Exporters", Journal of Business Research, (32:1), 1995, pp. 41-47.

Dickson, G.W., "An Analysis of Supplier Selection Systems and Decisions”, Journal of Purchasing, (2), 1966, pp. 5-17.Dobilas, G., and MacPherson, A., "Environmental Regulation and International Sourcing Policies of Multinational Firms", Growth and Change, (28:1), 1997, pp.7-23. 
Ellram, L.M., "The Supplier Selection Decision in Strategic Partnerships", Journal of Purchasing and Materials Management, (20:4), 1990, pp.8-14.

Evans, R.H., "Product Involvement and Industrial Buying", Journal of Purchasing and Materials Management, (18:2), 1982, pp. 23-28.

Giunipero, L.C., and Brewer, D.J., "Performance Based Supplier Selection Systems Under Total Quality Management", International Journal of Purchasing and Materials Management, (29:4), pp. 35-41.

Gustin, C.M., Daugherty, P.J., and Ellinger, A.E., "Supplier Selection Decisions in Systems/Software Purchases", International Journal of Purchasing and Materials Management, (33:3), 1997, pp. 41-46.

Hahn, C.K., Watts, C.A., and Kim, K.Y., "The Supplier Development Program: A Conceptual Model”, Journal of Purchasing and Materials Management, (26:2), 1990, pp. 1-7.

Hirakubo, N., and Kublin, M., "The Relative Importance of Supplier Selection Criteria: The Case of Electronic Components Procurement in Japan”, International Journal of Purchasing and Materials Management, (34:2), 1998, pp. 19-24.

Johnson, W., Patterns of Industrial Buying Behavior, Prager, New York, NY, 1981.

Katsikeas, C.S., and Leonidou, L.C., "International Supplier Selection: The Relevance of Import Dependence", Journal of Global Marketing, (9:3), 1996, pp. 23-45.

Krause, D.R., "Supplier Development: Current Practices and Outcomes", International Journal of Purchasing and Materials Management, (33:2), 1997, pp.12-19.

Krause, D.R., Scannell, T.V., and Calantone, R.J., "A Structural Analysis of the Effectiveness of Buying Firms' Strategies to Improve Supplier Performance”, Decision Sciences, (31:1), 2000, pp. 33-56.

Lambert, D.M., Adams, R.J., and Emmelhainz, M.A., "Supplier Selection Criteria in the Healthcare Industry: A Comparison of Importance and Performance", International Journal of Purchasing and Materials Management, (33:4), 1997, pp. 16-22.

Lambert, D. M., and Harrington, T.C., "Measuring non-response bias in mail surveys", Journal of Business Logistics, (11:2), 1990, pp. 5-25.

Lehmann, D.R., and O'Shaughnessy, J., "Decision Criteria Used in Buying Different Categories of Products", Journal of Purchasing and Materials Management, (18:1), 1982, pp. 9-14.

Lehmann, D.R., and O'Shaughnessy, J., "Difference in Attribute Importance for Different Industrial Products", Journal of Marketing, (38), 1974, pp. 36-42.

Mason, T., "Getting Your Suppliers on the Team”, Logistics Focus, (4:1), 1996, pp.10-12.

Min, H., LaTour, M, and Williams, A., "Positioning Against Foreign Supply Sources in an International Purchasing Environment", Industrial Marketing Management, (23:5), 1994, pp. 371-382.

Min, H., and Galle, W.P., "Green Purchasing Strategies; Trends and Implications", International Journal of Purchasing and Materials Management, (33:3), 1997, pp. 10-17.

Monczka, R. M., Trent, R. J., and Callahan, T. J., "Supply Base Strategies to Maximize Supplier Performance", International Journal of Physical Distribution and Logistics, (24:1), 1994, pp. 42-54.

Monczka, R.M., and Trecha, S.J., "Cost Base Supplier Performance Evaluation”, Journal of Purchasing and Materials Management, (24:1), 1988, pp. 2-7.

Narasimhan, R., "An Analytical Approach to Supplier Selection”, Journal of Purchasing and Materials Management, (19:4), 1983, pp. 27-32.

Nunnally, J., Psychometric Theory, McGraw-Hill, New York, NY, 1988 
Nydick, R.L., and Hill, R.P., "Using the Analytic Hierarchy Process to Structure the Supplier Selection Procedure", International Journal of Purchasing and Materials Management, (28:2), 1992, pp. 31-36.

Pan, A., "Allocation of Order Quantity Among Suppliers", Journal of Purchasing and Materials Management, (25:3), 1989, pp. 36-39.

Piercy, N.F., Katsikeas, C.S., and Cravens, D.W., "Examining the Role of Buyer-Seller relationships in Export Performance", Journal of World Business, (32:2), 1997, pp. 73-86.

Prahalad, C. K., and Hamel, G., "The Core Competence of the Corporation. Harvard Business Review, (68:3), 1990, pp. 79-91.

Ragatz, G.L., Handfield, R.B., and Scannell, T.V., "Success Factors for Integrating Suppliers Into New Product Development", Journal of Production and Innovation Management, (14:3), 1997, pp. 190202.

Soukup, W., "Supplier Selection Strategies", Journal of Purchasing and Materials Management, (23:2), 1987, pp. 7-12.

Swift, C.O., "Preferences for Single Sourcing and Supplier Selection Criteria", Journal of Business Research, (32:2), 1995, pp. 105-111.

Tan, K.C., Kannan, V.R., and Handfield, R.B., "Supply Chain Management: Supplier Performance and Firm Performance", International Journal of Purchasing and Materials Management, (34:3), 1998, pp. 2-9.

Thompson, K.N., "Supplier Profile Analysis", Journal of Purchasing and Materials Management, (26:1), 1990, pp. 11-18.

Thorelli, H.B., and Glowacka, A.E., "Willingness of American Industrial Buyers to Source Internationally", Journal of Business Research, (32:1), 1995, pp. 21-31.

Timmerman, E., “An Approach to Supplier Performance Evaluation”, Journal of Purchasing and Materials Management, (22:4), 1986, pp. 2-8.

Tully, S., "Purchasing's New Muscle", Fortune, (20), 1995, p. 76.

Turner, I., "An Independent System for the Evaluation of Contract Tenders", Journal of the Operational Research Society, (39), 1988, 551-561.

Verma, R., and Pullman, M.E., "An Analysis of the Supplier Selection Process", OMEGA: International Journal of Management Science, (26:6), 1998, pp. 739-750.

Vonderembse, M.A., and Tracey, M., "The Impact of Supplier Selection Criteria and Supplier Involvement on Manufacturing Performance", Journal of Supply Chain Management, (35:3), 1999, pp. 33-39.

Walton, S.V., Handfield, R.B., and Melnyk, S.A., "The Green Supply Chain: Integrating Suppliers into Environmental Management Processes", International Journal of Purchasing and Materials Management, (34:1), 1998, pp. 2-11.

Watts, C.A., and Hahn, C.K., "Supplier Development Programs: An Empirical Analysis", International Journal of Purchasing and Materials Management, (29:1), 1993, pp. 11-17.

White, P.D., Decision Making in the Purchasing Process: A Report, AMACOM, New York, NY, 1978.

Wilson, E., "The Relative Importance of Supplier Selection Criteria: A Review and Update", International Journal of Purchasing and Materials Management, (30:3), 1994, pp. 35-41. 


\section{APPENDIX 1: SURVEY ITEMS}

How important are the following factors when selecting a key/preferred supplier for your organization?

\begin{tabular}{|c|c|c|c|c|}
\hline & High & & & \\
\hline a. & Company size & 4 & 3 & \\
\hline b. & Ethical standards ... & 4 & 3 & \\
\hline c. & $\ldots \ldots \ldots \ldots \ldots$ & 4 & 3 & \\
\hline d. & 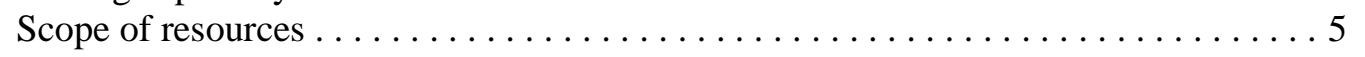 & 4 & 3 & \\
\hline e. & 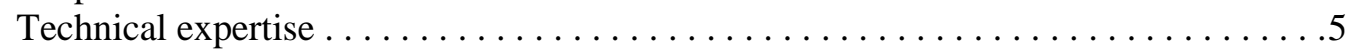 & 4 & 3 & \\
\hline & Industry knowledge $\ldots \ldots \ldots \ldots \ldots \ldots \ldots \ldots \ldots \ldots \ldots \ldots$ & 4 & 3 & \\
\hline g. & (2) & 4 & 3 & 2 \\
\hline h. & 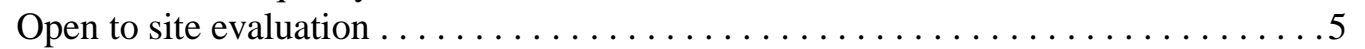 & 4 & 3 & 2 \\
\hline & Supplier's process c & 4 & 3 & 2 \\
\hline & history $\ldots \ldots \ldots \ldots \ldots \ldots \ldots \ldots \ldots \ldots \ldots \ldots \ldots \ldots \ldots \ldots \ldots \ldots \ldots$ & 4 & 3 & \\
\hline $\mathrm{k}$. & upplier $\ldots \ldots \ldots \ldots \ldots \ldots \ldots \ldots \ldots$ & 4 & 3 & \\
\hline & $y$ due dates $\ldots \ldots \ldots \ldots \ldots \ldots \ldots \ldots \ldots$ & 4 & 3 & 2 \\
\hline $\mathrm{m}$. & ene & 4 & 3 & 2 \\
\hline n. & 然 & 4 & 3 & 2 \\
\hline o. & 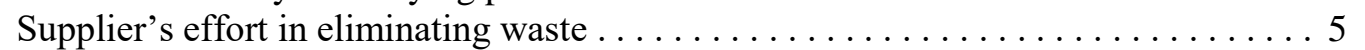 & 4 & 3 & \\
\hline p. & . & 4 & 3 & 2 \\
\hline q. & ns & 4 & 3 & 2 \\
\hline & 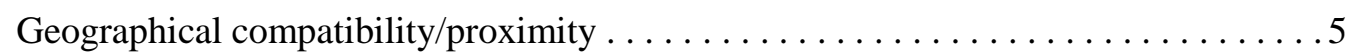 & 4 & 3 & 2 \\
\hline & Co & 4 & 3 & 2 \\
\hline & Pas & 4 & 3 & 2 \\
\hline & nciples . . & 4 & 3 & 2 \\
\hline & Sup & 4 & 3 & \\
\hline & 1 information $\ldots \ldots \ldots \ldots \ldots \ldots \ldots$ & 4 & 3 & 2 \\
\hline & bcontracted .............. 5 & 4 & 3 & 2 \\
\hline & der entry and invoicing system, including EDI .... & 4 & 3 & 2 \\
\hline & ir overall business . . . . . . . & 4 & 3 & 2 \\
\hline & oplying to you $\ldots \ldots \ldots \ldots \ldots$ & 4 & 3 & 2 \\
\hline & it relationship $\ldots . \ldots \ldots \ldots$. . . & 4 & 3 & \\
\hline & . & 4 & 3 & \\
\hline & serve capacity or tie aumly to iespond & 4 & & \\
\hline
\end{tabular}

How important are the following issues when evaluating your key/preferred suppliers' performance?

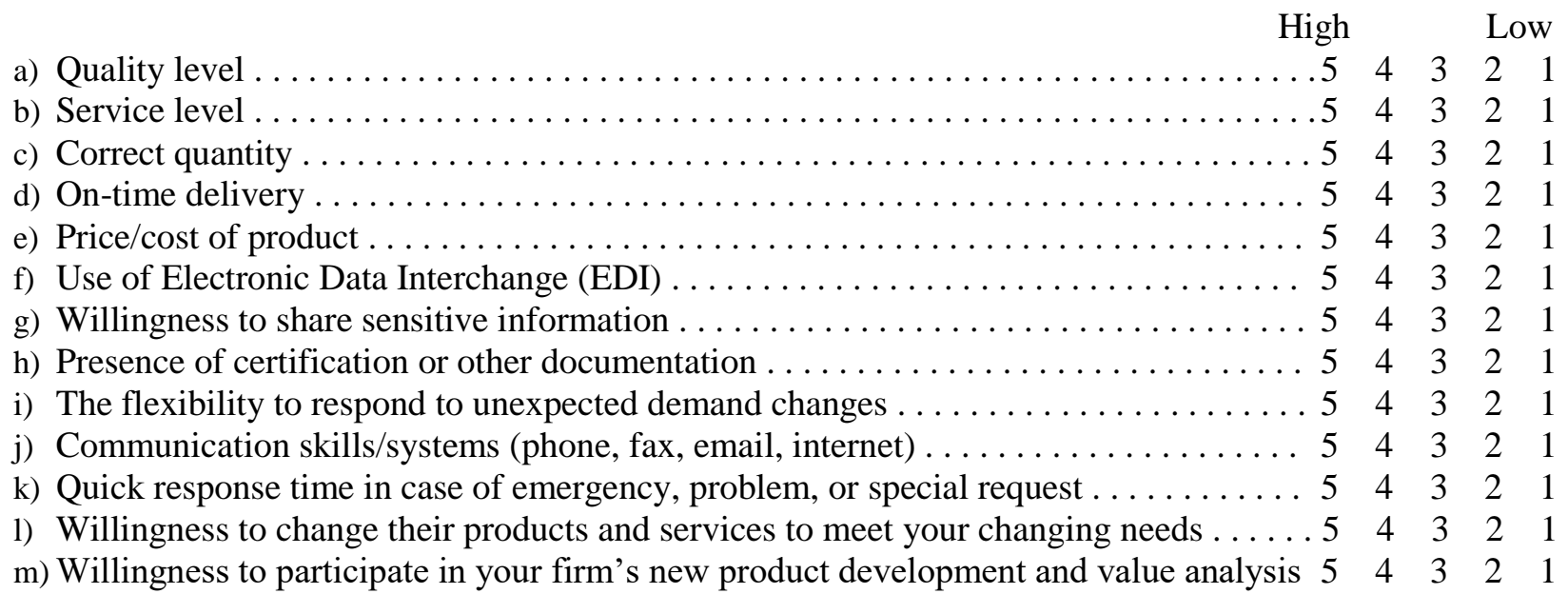


Indicate the level of your firm's performance compared to that of major industrial competitors in terms of

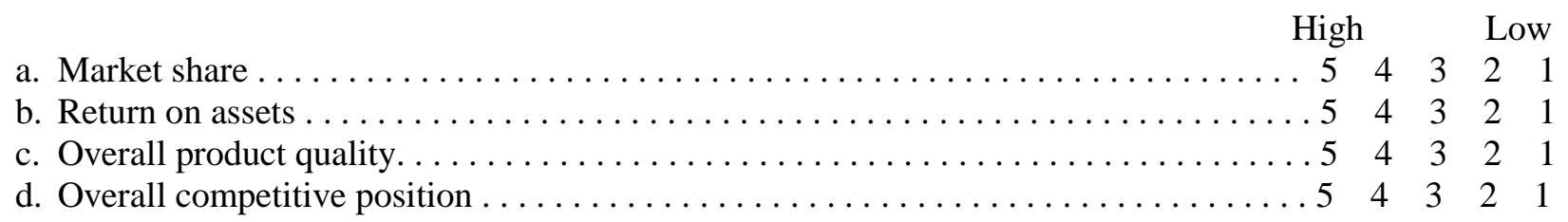

